Meta

Journal des traducteurs

Translators' Journal

\title{
Translating Ferron, Ferron Translating: Thoughts on an Example of "Translation Within"
}

\section{Betty Bednarski}

Volume 45, numéro 1, avril 2000

La traduction littéraire au Canada

Literary Translation in Canada

URI : https://id.erudit.org/iderudit/002017ar

DOI : https://doi.org/10.7202/002017ar

Aller au sommaire du numéro

Éditeur(s)

Les Presses de l'Université de Montréal

ISSN

0026-0452 (imprimé)

1492-1421 (numérique)

Découvrir la revue

Citer cet article

Bednarski, B. (2000). Translating Ferron, Ferron Translating: Thoughts on an Example of "Translation Within". Meta, 45(1), 37-51.

https://doi.org/10.7202/002017ar
Résumé de l'article

Dans le texte de La nuit (1965) et de sa version "corrigée", Les confitures de coings(1972), Jacques Ferron insère une traduction française d'un poème anglais de SamuelButler, attirant ainsi implicitement l'attention sur l'acte de traduire. S'élabore en même temps, dans la narration et les dialogues adjacents, une thématisation explicite de cet acte, qui se trouve, par le fait même, soumis à un questionnement critique. Quelle est la fonction de la traduction quand celle-ci s'effectue entre cultures "inégales" ? Quels textes traduit-on ? Qui les choisit? Qui réalise les traductions? Celles-ci serviraient-elles des fins précises ? La traduction est ainsi problématisée. Mais quel sens ce questionnement revêt-il pour le traducteur anglais? Comment celui-ci situera-t-il son travail par rapport à une telle remise en question de la traduction de la part de l'auteur lui-même? Telle est la question qui sous-tend ma lecture de la traduction inscrite au cœur de ces deux textes. 


\title{
Translating Ferron, Ferron Translating: Thoughts on an Example of "Translation Within"
}

\author{
BETTY BEDNARSKI \\ Dalhousie University
}

\begin{abstract}
RÉSUMÉ
Dans le texte de La nuit (1965) et de sa version «corrigée», Les confitures de coings (1972), Jacques Ferron insère une traduction française d'un poème anglais de Samuel Butler, attirant ainsi implicitement l'attention sur l'acte de traduire. S'élabore en même temps, dans la narration et les dialogues adjacents, une thématisation explicite de cet acte, qui se trouve, par le fait même, soumis à un questionnement critique. Quelle est la fonction de la traduction quand celle-ci s'effectue entre cultures «inégales »? Quels textes traduit-on? Qui les choisit? Qui réalise les traductions? Celles-ci serviraient-elles des fins précises? La traduction est ainsi problématisée. Mais quel sens ce questionnement revêt-il pour le traducteur anglais ? Comment celui-ci situera-t-il son travail par rapport à une telle remise en question de la traduction de la part de l'auteur lui-même? Telle est la question qui sous-tend ma lecture de la traduction inscrite au cœur de ces deux textes.
\end{abstract}

\begin{abstract}
In both La nuit (1965) and its "corrected" version, Les confitures de coings (1972), Jacques Ferron has inserted into his own text a French translation of an English poem by Samuel Butler, and through this insertion and the explicit thematization of translation that occurs in the surrounding passages of dialogue, he has foregrounded translation in an extraordinarily critical way. What is the function of translation between cultures of unequal power? What gets to be translated? Who chooses? Who produces the translation? Whose ends are being served? Through these implicit questions translation is being subtly problematized. But what meaning does all this hold for the English translator? How is he/she to situate translation in the light of the author's problematization of the act? This, ultimately, is the question underlying my translator's reading of these passages in Ferron's two texts.
\end{abstract}

\section{MOTS-CLÉS/KEYWORDS}

virtual translator, translating translation, translation within, French and English Canadian cultures, colonialism

I have always been interested in the ways in which the work I translate both invites and resists translation-English translation, I mean. And, like Sherry Simon, I'm fascinated by occurrences of la traduction "dans" les livres (Simon 1994: 18). What I'm going to present here is a close and curious translator's look at a moment in Jacques Ferron's work-a moment that constitutes an instance of trans-national reading ${ }^{1}$ and a very literal example of "translation within." It occurs in a text (it's spread across two texts, actually) that I myself did not translate. And while it has all sorts of implications for the English translator-and for translation in general-they are not, most of them, implications of a practical kind. This will not be a discussion of "problèmes de traduction," unlike most of what I've written on translation to date. But, like what I've already written, it is at once critical and intéressé. I hope 
comparatists as well as translators and translation scholars will find it interesting. I also see it as a contribution to Ferron studies, and in particular to the understanding of the complex phenomenon of cross-cultural literary affinities and antagonisms which Ginette Michaud has analyzed in "Lire à l'anglaise" (1995).

The French text of Ferron's 1965 novel, La nuit, and its 1972 “corrected version," Les confitures de coings, is studded with quotations-in English-from nature poems by English Canadian poets Charles G. D. Roberts, Bliss Carman, Duncan Campbell Scott and Frederick George Scott, all of which are attributed indiscriminately by the novel's narrator, François, to the father of his much loved, much hated English Canadian alter ego, Frank. Frank is a recurring character, whose referent-and Ferron made no bones about this_-was English Canadian poet and legal reformer F. R. Scott. For years, little of significance, and certainly neither death nor redemption, could happen to Québécois protagonists of Ferron's fiction without reference to this Frank, who can be seen as the embodiment of all that is despicable and admirable in the English Canadian. In La nuit he dies poisoned, enabling the narrator to recover his soul-his own, and by implication, Québec's. Les confitures de coings is a new version, reworked after the October Crisis, with a change of title to "stress" the poison (contained in a jar of quince jam).

So in these two novels-or these two versions of the same novel-lines from well-known English Canadian poets are incorporated into the text and attributed to the poet father of the fictional Frank. All this has been discussed by Guy Monette in Voix et images in 1983. I don't intend to comment on the typically "ferronien" use and abuse of other peoples' writing here, other than to stress that the quoting-or near quoting - of these English Canadians must be seen in the context of the inscription of English otherness (I've referred to it variously as English "alterity," "Englishness," "anglicite”) in Ferron's work (Bednarski 1989, 1990, 1995a, 1995b). This otherness manifests itself in a whole range of ways, including the incorporation of English characters into the fiction and the presence of those untranslatable gallicized English words that have inspired almost everything I've written on translation to date. Much of what I will have to say today can be traced back to my ongoing relationship with these "mots déguisés." But I want to focus here on the insertion of English poetry in La nuit and Les confitures de coings. Not the Canadian poetry I've just mentioned, which appears in English, but a satirical poem by Samuel Butler, a kind of "honorary" Canadian poem, since it was inspired by the author's visit to Montreal in 1875 and is entitled "A Psalm of Montreal." This poem by Butler appears not in English, but in French. It is a translation, and in the first version of the novel it is explicitly identified as such.

I have already signalled elsewhere the presence of a "virtual" English translator in Ferron's work. So important were the instances of fictional English reception-of the inside outsider listening, contemplating, reading, narrating (and in its ordering and making sense of reality, narrating was reception of a kind) - so important were these instances of reception, then, that I was surprised, in the course of my own early reading, not to find at least one example of an active English translator at work in one of Ferron's texts. But the translator was not really absent. He/she was there in the 
person of Frank. Now, one of Frank's antecedents in Ferron's fictional universe had been an Englishwoman who, in the short story "Le pont," crossed the Cartier Bridge in search of scrap, plying her way with her horse and cart between Montreal and Longueuil. Remember, "bridge" is one of the oldest metaphors for translation and the dominant one in Canadian discourse on translation in the 1960's and the 1970's. Frank never crosses the bridge-that is, never literally. As I wrote in 1995, Frank could be seen as a kind of "passeur en puissance" by virtue of his association with the fictional Englishwoman and with his referent, so persistently identified by Ferron as F. R. Scott (Bednarski 1995a: 208). Scott was the translator of Quebec poets SaintDenys Garneau and Anne Hébert into English. So Frank seemed to me to be, by association, a virtual translator. What I want to show you now is that Frank actually did translate. He does at any rate claim to have translated one text-at least in $L a$ nuit. It is Butler's satirical "Psalm of Montreal." So that, curiously, when we see him translating, it is not into English, but into French.

Butler's poem is a comment on the prudish atmosphere that prevails in late 19thCentury Montreal, where, shoved away in a back room of the Natural History Museum and gathering dust, its offending piece of private anatomy facing the wall, he has found a plaster cast of a famous Greek statue. He is informed by an employee of the museum, a stuffer of owls and such, that the Discobolus-as it is called-is not fit for public view, since it has no "pants" to wear. Butler makes fun of the prudery, the lack of culture, the indifference to beauty, and the Canadian use of the word "pants."

The French translation of the poem occurs in Chapter 5 of both La nuit (1965: 77-78) and Les confitures de coings (1972: 183-184). Butler has come up early on in the night-time conversation between François, the narrator, and Frank. Frank has referred to Butler's theories on memory, every bit as important in his view as those of Proust. And this little scene opens the way for two lyrical evocations of childhood memories, first by Frank, then by François. The two walk and talk as they make their way to Frank's night-club, where Frank will succumb, apparently poisoned by François" "gift" of home-made quince jam. That is the setting.

In La nuit, the poem is identified as a translation, and Frank as the author of that translation. Frank recites his French version of four of the original poem's seven verses. Halfway through, he stops, and we read this short exchange:

- Le connaissiez-vous?

- Non, pas du tout.

- Nous n'existons donc pas pour vous! Et pourtant vous devriez le savoir: Montréal est une ville à direction écossaise. (1965: 77)

He then recites two more verses and adds:

- C’est moi qui ai traduit ce poème. (1965: 78)

In Les confitures de coings things happen a little differently. For a start, only three of the verses are quoted, and one of these only incompletely. In the third quoted verse a line has been changed. But the most important changes occur in additions and 
modifications to the surrounding text. There are some notable omissions. The Québécois narrator says more now than Frank. The conversation is less one-sided. The narrator has taken a more assertive stance. And, curiously, in this "corrected" version, Frank no longer mentions that he has done the translation himself, nor does he say anything to indicate that translation is what this is (1972: 183-184).

Frank's “Nous n'existons donc pas pour vous!" evokes what Doug Jones, writing in 1977, has called "the cry to be heard, to be recognized, to be given existence in the eyes of others"-in this case we could say "the Other" (Jones 1977: 78). Jones is talking about the urgent need for the kind of cultural knowledge that is mediated by translation, and the confirmation of existence it ensures. This confirmation is as necessary to the English Canadian as it is to the Québécois. "Nor," he writes, "are English-Canadians possessed of such a large and assured identity that they have no need of such reinforcement" (Jones 1977: 80). Since Jones' perspective is translation, it is interesting to remember that in the 1960's and 1970's relatively little translation of English Canadian writing was being done into French-only about half as much as was being done in the other direction (Stratford 1977: v). Frank's exclamation could be just such a "cry to be heard," and the exclamation mark, more than anything, a sign of distress. The narrator of Les confitures de coings adds, however, "Cela lui déplut ...," leaving less room for interpreting the tone (1972: 183). Interestingly, translator Ray Ellenwood has Frank "crestfallen" (Ellenwood 1977: 147), which goes along well with the idea of distress, and is in keeping with the at times pathetic image of a misguided but well-meaning Frank, increasingly out of touch, as the novel progresses, with his time and space. "Adieu," he says at the end of the novel, "j'ai vécu du mauvais côté du mur" (1965: 130; 1972: 228). But it doesn't quite convey what I think is implied in the new, tougher text: irritation, displeasure, annoyance even. Annoyance at having his expectations thwarted, or at not receiving his due ... At the very least, I think he is "miffed."

Look back to La nuit now, where Frank's exclamation is followed by the interesting remark about the Montreal "Scottish" (read "Anglo") establishment: "Montréal est une ville à direction écossaise" (1965: 77). There is as much ambiguity and irony in Frank's speech as in other parts of Ferron's text. Is Frank simply referring here to Montreal's puritanical mindset, laying the blame for it, so to speak, at the door of the stuffy Scots? Or is it a reminder of the power wielded by the minority and an indication, therefore, that it is not just "existence in the eyes of the Other," but acknowledgement of dominance that he seeks? This comment is removed in the 1972 version. En revanche, François, with post-1970 lucidity and assertiveness, remarks (to himself and outside of dialogue-so, retrospectively) that Frank should have realized (no doubt did realize) that "existence in the eyes of the Other" also implies reciprocity (“Sans doute eut-il le temps de penser que la réciproque était vraie.") ... (1972: 183). In this case: not only do you not exist for $u s$, but nor do we for you.

So Frank is seeking confirmation. And when, in La nuit, he adds the final piece of information about the translation's authorship, he is by implication associating translation with that confirmation (of existence? of dominance?). And translation is being presented as self-initiated, self-authorized, possibly neither requested nor 
authenticated by francophone Québec. For a culture more and more aware of itself as "une culture traduite," such a unilateral initiative could have a familiar ring.

In choosing to recite in French, Frank has taken an important step. François, the narrator, has already shown himself to be quite capable of understanding Frank's lyrical outpourings in English. Some clever play in the integrating of the quotes gives incontrovertible evidence of this (and by implication, I should add, of Ferron's own knowledge of English) (1965: 54-57; 1972: 164-166). At the point when François begins his quest to reclaim his soul from Frank, he has been assimilated into Frank's world, functioning in English, a "simulacre anglais de [lui]-même" (1972: 169). We are told the two converse together in English as well as in French. Sometimes Frank uses his native "langue forestière" (Ferron's term for "speaking white"), sometimes his elegant European French (François tells us so, all conversations-unlike the poetrybeing reported in French, so that, incidentally, there is, by implication, translation going on in that reporting all the time). Clearly, Frank did not need to resort to translation-his own or anyone else's - in order to communicate this poem to François. He certainly never bothered in the case of the nature poems. Why would he choose to do so here?

Already the barrage of English Canadian literary quotes amounts to fairly aggressive promotion of Frank's own culture in English. It suggests an underlying assumption of the relevance of the words of the poets to Quebec (most of them are known, by the way, as "The Confederation Poets" to us). That they are not considered relevant by the narrator is of course one implication of Frank's death by poisoning at his hands, and in Les confitures de coings, François offers a long home-grown poem in French, supposedly by a member of his own Maskinongé family, "le cousin Rodolphe," and comprising in total many more lines than Frank had managed to produce in English and French combined, righting a balance-indeed, tilting it resolutely the other way (1972: 195-198). Frank's choice of French for the Butler poem could be seen as a gesture towards the culture of his interlocutor, could reflect some generosity of spirit on his part, some attempt at accommodation of that culture's sensitivities. On the other hand, in the context of François' search for his own and Québec's soul, Frank's translation is still a version of the inescapable word of an inescapable Other. The translated passages are just as blatantly self-promotional as the English ones, even more blatantly so, perhaps, because when it comes to pushiness, translation has the edge.

So why choose that much "pushier" mode? Why single this particular text out for special treatment? Why not simply forgo translation once again? The decision of course is Ferron's, ${ }^{2}$ and in the fiction, Frank's. The element that makes this poem different from the rest and "worthy" of translation, so to speak, is its critical dimension, its mocking tone. Frank appears here to be eager to share with the Québécois an uncharacteristically critical view of his own culture, showing English Canada to be capable of laughing at itself.

Of course, this is in actual fact not a Canadian poem at all, but a British one, and what we are seeing is a classic "put down" of the "colonial" by the bemused British visitor, touring the colonies and observing the locals from the vantage point of cultural 
superiority. Seen in such a "colonial" perspective, the "put down" could in theory bring French and English Canadians together, create a kind of colonial solidarity. Or-why not?-a Montreal solidarity. That could be part of Frank's motivation here. To the extent that the Montrealers targeted, and the owl-stuffer in particular, are not identified explicitly as French or English, both groups could surely be expected to laugh together at Montreal's-and their own-expense. However, the fact that this is an outside poem-an outside outside poem - appears to be lost on the Québécois who, in his final comment (this comment, added, you will remember, in the politically-corrected version of 1972), makes no distinction between English Canadian and British. "[V]os compatriotes," he says. As if all that mattered was one big supra-national categoryles Anglais. "Ce n'est pas dans les habitudes de vos compatriotes de se déprécier" (1972: 184). It's true that he's not saying in so many words that English Canada-oh miracle! - has generated its own self-critical text, though I think it's natural to first assume that he is saying this. He could simply be referring to the English Canadian's capacity for appreciation of the criticism directed at him in the British poem-selfdeprecating appreciation, you might say (it does sound like a very Canadian attribute). While that could well be the case, the effect of the remark is to gloss over the fact that the Canadian was in the first place the butt of someone else's joke.

François is, of course, responding to a translation, and while careful consideration of the French version itself falls outside of the scope of this reading, it is worth noting that the colonial dimension is an object of erasure in the text he hears. Whereas in the English the "trousers"/"pants" opposition refers to linguistic divergence between the colonial power and the colony, the old world and the new, in French the pairing of "culottes"/ "inexprimables" sets up a very different network of social and moral resonances, and at the same time signposts an instance of the untranslatable-or "inexpressible" - in the original English poem. ${ }^{4}$ But colonialism is not so much unexpressed as it is relocated. Erased at one point in the translation, it surfaces-reconfigured-elsewhere. And this time it is not lost on the Québécois.

In his final commentary (which in the new version replaces Frank's "C'est moi qui ai traduit..."), the narrator goes on to reveal a deep-seated mistrust of messages originating in the dominant culture: "Ils peuvent tout mettre sur notre compte en fait de ridicules et de sottises." And, adding a whole new twist, "Il doit exister une version de ce poème où le beau-frère [...] est un brave CF, victime de ses curés” (1972: 184). Even an ostensibly innocent and self-deprecating gesture on the part of the sympathetic English Canadian Other can have negative implications for Québec. For translation is not innocent. François' remark suggests that translation is complicitous, or that at the very least it should be considered suspect. "Il doit exister une version ..." Not necessarily a translation. But translation is only a "version," and from original to version, from version to version, de fil en aiguille, new messages can be produced-or hidden messages come to light. In the English poem the target could be seen as culture neutral-blandly, non-specifically "Canadian." ${ }^{5}$ While the very inclusivity of the English word already conveniently subsumes Quebec, it is in French-and thus through the act of translation-that the poem's colonizing potential has been fully realized. Through cracks opened by the adjective "canadien," the infiltration has taken place, because in that designation the Québécois' historical sense of his language will allow him to recognize first and foremost himself. Not just himself also, but first and foremost himself. 
Does it matter any more whether the poem is English Canadian or British? I think not. "[V]os compatriotes ..." says François. That one is a primary, one a secondary colonizer is irrelevant. What counts is that as a result of a slippage of meaning it is now the Québécois who is being colonized. In the guise of English Canadian selfcriticism, is Frank "selling" just another demeaning image of Québec? Frank is not responsible for the potentially restrictive meaning of "canadien" in French, but he is the vehicle for the transmission of that meaning here, and, while there is no suggestion that he has set out, deliberately, to divert, could that meaning not have been "lurking" already, even before French-just below the surface of consciousness, perhaps-in the English Canadian mind? ${ }^{6}$

François has the Québécois' heightened awareness-again it is an historical awareness - that sooner or later cultural transaction between dominator and dominated will end up being to the detriment of the latter, his suspicion, too, that derision often lingers in the darker recesses of an otherwise enlightened mind, and that images projected by the Other can be instrumental in defining Québec in its own eyes. The poor French Canadian, "victime de ses curés"... We know with what vigour Ferron condemned the Jean Lemoynes of Québec, who elaborated the fake image of "Jansenist" oppression from within their own culture, projecting it to the outside world. And we know that English Canada has not hesitated to buy into this stereotype and to beam confirmation confidently back to Québec.

To François' comment, Frank merely replies, laconically: "Possible," at the very least acknowledging that François could be right. "Cela ne l'avait pas empêché de me le réciter.” Is translation, then, an insensitive act?

In Les confitures de coings, Ferron no longer flags Frank's authorship of the translation, as he had in La nuit. Nor is translation mentioned by name. But, surrounded as it is by passages of untranslated English verse, Butler's poem still stands out as translation in contrast to these, precisely because it is in French. Translation has been foregrounded in both versions of the novel, and in an extraordinarily critical way. That is to say that it is at the same time valorised as a means of transmitting cultural knowledge and of giving (and achieving) existence in the eyes of an Other, and regarded with suspicion, because of its ability to shift meanings, and its relationship with power. What is the function of translation, Ferron seems to be asking, between cultures of unequal power? What gets to be translated? Who chooses? Who produces the translation? Whose ends are being served? The answers are never clear cut, if indeed there are answers at all. But through the implicit questions, translation is being subtly problematized. The existence of two versions of the same novel only serves to add complexity. Development over time has allowed even richer ambiguity. Reading the two texts together gives a rare opportunity to see, in all its elusive, living, moving contradiction, a Québec writer's confrontation of the possibility of translation, its dangers, its necessity.

What is the significance of all this for the translator translating? La nuit has never been translated into English. So no translator has ever had to worry about Frank's 
"C'est moi qui ai traduit ...," which would have drawn attention to the little inconsistency that arises when original English quotes from the nature poems and the French translation of Butler's "Psalm" all end up looking the same- the same as each other, and the same as the main body of the text. And when we read Les confitures de coings in English, because Frank's remark is absent, there is no way of knowing-or even surmising - that in this particular case Frank is not once again reciting in English, no possible way of knowing, then, that French translation has been visibly incorporated into Ferron's text. The italics used in the Exile edition of Ray Ellenwood's Quince Jam signal verse, as distinct from prose, not language change. So that, typographically and linguistically, the English Canadian nature poets, Butler and the poet cousin"cousin Rodolphe" - are absolutely identical. In translation, the "translation within" has vanished from the page.

For the translator translating, there is an inherent "problème de traduction" in all this. For the translator reflecting, this difficulty is a fascinating example of the way in which a text can resist. How do you translate translation? How many times, I wonder, has that question been asked? But I'm more concerned here with the explicit thematization of translation that is taking place, with what is being said, literally said (and not said), in this little scene. What meaning does this thematization hold for the English translator? How is he/she to situate translation in light of the author's problematization of the act? This, ultimately, is the question underlying my reading of these passages in Ferron's two texts.

Why, I have to ask myself, in Les confitures de coings, would Ferron have removed that reference to the authoring of the translation by Frank? And, why is translation itself not named? I confess I'm still trying to find possible answers to that. In the politically charged climate of "congédiement" (Ferron retroactively "sacks" his recurring character in this new version's "appendice" (1972: 263)), in that politically charged climate, Ferron heaps abuse on Frank. Explicit in so many other ways about Frank's betrayals, why is the text silent here? If translation is invidious, why would Ferron not have added it, for good measure, to the list, accusing in Frank the "traducteur traître" along with the "anglican déchu [...] qui se prend pour un demi-Dieu," the "policier légiste," the "pseudo-politicologue," the "vil procédurier"? I'm puzzled. Perhaps the implicit accusation is felt to be more powerful, because it is more subtle? Or, could it be that, in spite of everything, beyond the political, translation still has value, prestige? Could there be a need to protect translation, to distance the literary pursuit from other more overtly political activities? And could this, I wonder, be the meaning-one of the meanings-of dedication? Les confitures de coings is dedicated to an English translator. ${ }^{7}$ Would dedication - this relocation outside the novel, in a still ambiguous but nevertheless protected space-perhaps allow Ferron to retain for translation, outside of the political débâcle, just a little way away from it, a foothold, a... "niche"? Perhaps for translation "tout n'est pas perdu"? Perhaps, through this authorial gesture, translation has been made temporarily "safe"?8 
That translation, too, can resist, that is that it can ultimately aspire to a trans-national space (not the "trans" of "across," this is not the "trans" of national border-crossings, but the "trans" of transcending them), is that perhaps a translator's fancy? But if so, it is a writer's fancy too. "Écrire en paix, sans souci du pays...," wrote Ferron to JeanMarcel Paquette (Marcel 1970: 19). And this, in Du fond de mon arrière cuisine: "On écrit à un niveau qui n'est pas sujet aux lois de la société pour la bonne raison qu'on écrit en dehors de toute société et qu'on sera lu par un solitaire de même acabit, non pas par un citoyen; par un complice. C'est pour lui seul qu'on écrit"...(1973: 175). "En dehors de toute société," I wrote, "la traduction, cette belle complicité" (1989: 120). I don't know if it can exist. I do know that even in the midst of the vehement political recriminations of Les confitures de coings Ferron's narrator could ask of Frank: "Frank que serons-nous aux yeux de cet homme nouveau sur le point d'apparaître? Verra-t-il une différence entre un Écossais et un Canadien-français? J'en doute, et si j'ai peine à te haïr c'est peut-être que ma haine est déjà périmée" (1965: 81; 1972: 186-187). So, even at the heart of this most political, most polemical of novels, there is expression of the aspiration to transcend.

But most heartening of all for translation is an astonishing authorial intrusion a little further on in the same text: "Un peu Baluba, mon cher Frank, notre roman." The connotations of "Baluba" would be interesting to explore, especially in relation to the colonial context, but it's the "notre roman" that I want you to contemplate now, briefly, with me. It is, I think, one of the most extraordinary examples of EnglishFrench collaboration in Ferron's work. As characters (and it is important to remember that they are doubles as well), Frank and François are, of course, joint participants in the same fiction. They are also co-generators, at many levels, of the novel's narrative. But inasmuch as it occurs in an author's aside, the "notre" is more than anything suggestive of author-reader complicity, and it involves Frank in the kind of imagined co-authoring anticipation of reception implies. Collaboration is being situated here in the realm of the literary, as co-créativité. Here is the idea of the Anglais as constituent Other-constituent not just of Québecois identity, but of the literary work itself. About this collaboration-which could be seen to encompass the reading that is translation-I have written, recently:

Une des collaborations les plus étonnantes est celle qu'évoque le narrateur de La nuit et des Confitures de coings dans une petite phrase au ton badin, désinvolte, complice, qu'il prononce sur le mode dépréciatif, il est vrai, et comme malgré lui ... "Un peu Baluba, mon cher Frank, notre roman." Cette phrase a la légèreté de l'aparté et l'énorme poids du lapsus (d'auteur). Son possessif fait rêver ... (1999: 132) ${ }^{9}$

Rêvons donc... Je vous laisse rêver!

One final question remains to be asked of Ferron's "translation within": Where does it come from? What is the source of the French we read? My first attempts to answer that question were exercises in imagining.

Did this translation originate with the author of the fiction, created by that author to place in the mouth of the fictional translator, Frank? In other words, could I take it that Ferron himself had produced it, that he had himself literally translated 
here? This would be a natural enough assumption to make, but I knew I could assume nothing in the presence of an author notorious for unacknowledging his sources (un-acknowledging-the term is Ray Ellenwood's (Ellenwood 1976: 11)) and who in these same novels had raided the English Canadian poets and reassigned authorship so arbitrarily. It came as no great surprise to discover, eventually, that Ferron had "found" an existing translation (just as he "found" the English Canadian poems), simply bypassing the translator, the French writer Valéry Larbaud, and attributing his work to the fictional Frank. ${ }^{10}$

For a time, though, I did enjoy contemplating the idea that Ferron might possibly have translated the poem himself. And in fact, while the translation used is undoubtedly Larbaud's, ${ }^{11}$ one of the changes that has taken place between the first and second versions of the novel would seem to indicate that Ferron had at least some small hand in what we read. Not only has the number of verses recited been cut back from four to three, there is also a textual change. Butler's "Who seasonest the skins of Canadian owls," which is rendered in 1965 as "Qui prépares aussi les peaux des canadiennes chouettes" (Larbaud's exact words), becomes in 1972 "Empailleur attitré de toutes les chouettes canadiennes." I leave you to ponder the possible significance of the actual change in wording. But for our purposes, surely it is not unreasonable to suggest that Ferron, responsible for all other modifications of his 1965 text, has, at the very least, himself re-translated here?

I also explored the connection with F. R. Scott. ${ }^{12}$ I like to think that Ferron was led to the poem by Scott, and if not by him personally, then at least by his fascination for Scott, his curiosity about him, and a sense of affinity for the disrespectful vein in Canadian letters, which Scott represents. In 1957 Scott published, as co-editor with A. J. M. Smith, The Blasted Pine: An Anthology of Satire, Invective and Disrespectful Verse, Chiefly By Canadian Writers. "A Psalm of Montreal" was included (1957: 4546). So by association, Butler's poem had become Canadian. If it was, as I said at the outset, an "honorary" Canadian poem, this was in part thanks to Scott and Smith. There is no way of knowing whether Ferron first came across the poem in English or in Larbaud's French, but I like to think he discovered it in The Blasted Pine. I know that, like Scott and Smith, he would have delighted in the irreverence, the blasting of complacency, that characterize this collection of verse. To leaf through the Anthology (and I have done that, imagining him doing the same) is to get a sense of where Ferron's eye might have been drawn. And my own reading has suggested to me several possible connections with moments in Ferron's work. I notice, for example, in the "Introduction," a reference to the "vaporous rhapsodies of the Maple Leaf school of patriotic nature poets" (1957: xvi)—the very poets whose lines Ferron has woven into his French text-and I am struck by Scott's own "making over" of a poem by Charles G. D. Roberts, which Ferron too has "used” ironically (1965: 58; 1972: 167). It is Roberts" "Kinship"; "The Call of the Wild," Scott calls it:

Make me over, Mother Nature,

Take the knowledge from my eyes,

Put me back among the pine trees

Where the simple are the wise.

Clear away all evil influence

That can hurt me from the States. 
Keep me pure among the beaver

With un-Freudian loves and hates [...] (1957: 59-60)

Indeed, the editors of the Anthology state that their aim is to sound a "note which has generally been drowned out in the diapason of praise with which Canadian poets have hymned the glories of the True North Strong and Free" (1957: xv), setting up the very same opposition Ferron's text implies between the nature poems and Butler's.

I like, then, to entertain this idea of Ferron himself translating, albeit partially, something brought to him—put in his way, so to speak-by the anthologizer/commentator/facilitator, Scott. I have to admit, too, that before I discovered Larbaud's version, I also considered the possibility that the Butler's translation might have been authored by Scott. La nuit could, I reasoned, be pointing us quite straightforwardly (as it does in so many other instances) in the direction of the real-life Frank. (Scott, as I've mentioned, was well-known for his translations, though not for translation into French.) There is, after all, a natural compatibility between anthologizer and translator. A translator too can select. Both share their discoveries, both initiate new receptions in a similarly active way. In this case, I wondered, might translation have been just a natural enthusiastic next step for a keen anthologizer to take?

The sophistication of the French made it unlikely Scott had produced it on his own, and for a time I also allowed myself to consider the even more appealing possibility that Ferron and Scott might have translated together. To contemplate this hypothesis was to imagine a collaboration which, while it could not be confirmed in biography, was nevertheless quite compatible with the kinds of possibilities suggested-or, if you like, authorized-by Ferron's text (texts). Notre roman... "Notre" traduction? Might there have been co-authorship of this very literal kind? It was not unimaginable. True or not? Until I had located Larbaud's translation, it was impossible to say. But unimaginable it was not. And that, in the kind of back-and-forth, inand-out reading I like to engage in-back and forth between fiction and biography, in and out of literature and life-was sufficient for me. Fiction, biography. Literature, life. It is, after all, in the "not unimaginable" that we accomplish the necessary, the vital passage between...

There is in La nuit and Les confitures de coings an invitation to imagine, to conjure up French-English creative collaborations of many different kinds. Translation-that most privileged and at the same time most problematic of receptions-is foremost among these. Ultimately, the two texts could be said to anticipate their own reception in the English Canadian mind. That is one implication of Ferron's "translation within." It is also, for me, the most compelling of the multiple "meanings" generated by the "notre" that binds together François and Frank.

\section{NOTES}

1. This article was originally presented as a paper in Montreal at the annual conference of the American Comparative Literature Association (ACLA), April 10, 1999, in the context of a colloquium entitled "La littérature québécoise: entre le national et le trans-national." The session topic was "Ecrivains et traducteurs: devant la langue de l'autre / Inside and Out: The Translation Process." 
2. Butler was a writer for whom Ferron seems to have felt some affinity. There could be many reasons for this. See Smith (1983) and Michaud (1995).

3. I myself have been unable to locate any other occurences of inexprimables as an item of clothing. It would seem to be a calque of the English euphemistic "unmentionables" and inexpressibles, which, however, do not occur in Butler's text.

4. There is scope for an article on the French translation itself. I am grateful to ACLA Conference participants for the lively and far-reaching discussion of outer-/underwear which followed my paper-and particularly for insights regarding those inexprimables.

5. The adjective appears twice, referring to a species of owl and its range, but also, by implication, to the human society that occupies the same geographic space.

6. That it was, in fact, well above the surface is suggested much later on in the novel by a reference to Frank's notebook: "Les Canadiens, avait écrit Frank Archibald Campbell dans son Gotha - et par Canadiens il entendait les Québécois — [...]" (1965: 128; 1972: 226).

7. The dedication reads "à madame Élizabeth Bednarski."

8. Readers of Ferron will recognize here the reference to Ferron's historiette "Tout n'est pas perdu," in which he refers to the Scott family's souvenir pennies and jar of marmalade, which were said to have been placed in the base of the Wolfe monument in Quebec, surviving miraculously when the monument was blown up by terrorists in 1963 (1969: 104).

9. In this article I also allude briefly to the case of the Butler poem, but the references made there to Ferron's two novel texts are incomplete, and, I regret to say, inexact (1999: 156).

10. The translation of Butler's Notebooks (Carnets, translated by Valéry Larbaud, 2nd ed., Paris, Gallimard, 1936) is in Ferron's personal library. The pages (379-380) where the poem appears have been cut out. I am grateful to Luc Gauvreau and Madeleine Lavallée-Ferron for their help in discovering this.

11. With the exception of small editorial changes to one line, the translation appearing in La nuit is identical to Larbaud's. "Et pour cela tu brûles en Enfer, et que le Seigneur aie pitié de toi!" has been changed in Ferron's text to "Et pour cela tu brûles en Enfer—que le Seigneur ait pitié de toi!"

12. The Scott-Ferron relationship has often been discussed. See Bednarski (1989: 131-139). See also Djwa (1987: 418-422), Olscamp (1992), Velguth (1998) and Godbout (1999).

\section{REFERENCES}

Bednarski, Betty (1989): Autour de Ferron: littérature, traduction, altérité, Toronto, GREF.

- (1990): "Préface," Jacques Ferron, Les Roses sauvages, Montreal, VLB, pp. 9-19.

- (1995a): “De l'anglicité chez Ferron: retours et prolongements," L'Autre Ferron (Ginette Michaud, ed.), Montreal, Fides, pp. 199-220.

— (1995b): "From Ouèredéare to Soçaurez: Translating the English of Jacques Ferron," Culture in Transit: Translating The Literature of Quebec (Sherry Simon, ed.), Montrea1, Véhicule Press, pp. 110-132.

- (1999): "La traduction comme lieu d'échanges," Échanges culturels entre les Deux solitudes (Marie-Andrée Beaudet, ed.), Ste-Foy, Presses de l'Université Laval, pp.125-163.

DJwa, Sandra (1987): The Politics of the Imagination: A Life of F. R. Scott, Toronto, McClelland and Stewart.

Ellenwood, Ray (1978): "How Not to Quince Words," Books in Canada, 5-5, pp.8-11.

- (tr.) (1977) Jacques Ferron, Quince Jam, Toronto, Coach House Press.

Ferron, Jacques (1965): La nuit, Montreal, Éditions Parti pris.

- (1969): Historiettes, Montreal, Éditions du Jour.

- (1972): Les confitures de coings et autres textes, Montreal, Éditions Parti Pris.

- (1973): Du fond de mon arrière-cuisine, Montreal, Éditions du Jour.

Godвоuт, Patricia (1999): “'Des livres à la fois si proches et si lointains': les échanges littéraires à Montréal durant les années 1950," Échanges culturels entre les Deux solitudes (Marie-Andrée Beaudet, ed.), Ste-Foy, Presses de l'Université Laval, pp. 81-90.

Jones, Douglas G. (1977): “Grounds for Translation/Raisons d'être de la traduction” (tr. Joseph Bonenfant), Ellipse, no. 21, pp. 58-91.

Larbaud, Valéry (tr.) (1936): Samuel Butler, Carnets, Paris, Gallimard (2nd ed.). 
Marcel, Jean (Jean-Marcel Paquette) (1970): Jacques Ferron maIgré lui, Montreal, Éditions du Jour.

Michaud, Ginette (1995): “Lire à l'anglaise," L'Autre Ferron (Ginette Michaud, ed.), Montreal, Fides, pp. 137-197.

Monette, Guy (1983): "Les poètes de la Confédération dans Les confitures de coings de Jacques Ferron," Voix et images, 8-3, pp. 421-426.

Olscamp, Marcel (1992): “Jacques Ferron ou le nationaliste ambivalent," Littératures, 9-10, pp. 195-220.

Sсотт, F.R. and A. J. M. Smith (eds.) (1957): The Blasted Pine: An Anthology of Satire, Invective and Disrespectful Verse, Chiefly by Canadian Writers, Toronto, MacMillan.

Simon, Sherry (1994): Le trafic des langues: traduction et culture dans Ia littérature québécoise, Montreal, Boréal.

Smith, Donald (1983): “Jacques Ferron et les écrivains," Voix et Images, 8-3, pp. 437-453.

Stratford, Philip (1977): Bibliography of Canadian Books in Translation: French to English and English to French / Bibliographie de livres canadiens traduits de l'anglais au français et $d u$ français à l'anglais, Ottawa, HRCC/CCRH.

Velguth, Madeleine (1998): "La nuit dans un sac: étude des Confitures de coings de Jacques Ferron," Quebec Studies, 25, pp. 38-79.

\section{APPENDIX}

A Psalm of Montreal ${ }^{\star}$, by Samuel Butler

N/CC 1 Stowed away in a Montreal lumber room

The Discobolus standeth and turneth his face to the wall;

Dusty, cobweb-covered, maimed and set at naught,

Beauty crieth in an attic and no man regardeth:

O God! O Montreal!

N 2 Beautiful by night and day, beautiful in summer and winter,

Whole or maimed, always and alike beautiful -

He preacheth gospel of grace to the skin of owls

And to one who seasoneth the skins of Canadian owls:

O God! O Montreal!

3 When I saw him I was wroth and I said, "O Discobolus! Beautiful Discobolus, a Prince both among gods and men! What doest thou here, how camest thou hither, Discobolus, Preaching gospel in vain to the skins of owls?"

O God! O Montreal!

4 And I turned to the man of skins and said unto him, "O thou man of skins, Wherefore hast thou done thus to shame the beauty of the Discobolus?" But the Lord had hardened the heart of the man of skins And he answered, "My brother-in-law is haberdasher to Mr. Spurgeon."

O God! O Montreal!

N $5 \quad$ "The Discobolus is put here because he is vulgar -

He has neither vest nor pants with which to cover his limbs;

I, Sir, am a person of most respectable connections -

My brother-in-law is haberdasher to Mr. Spurgeon."

O God! O Montreal!

N/CC 6 Then I said, “O brother-in-law to Mr. Spurgeon's haberdasher, Who seasonest also the skins of Canadian owls, Thou callest trousers 'pants', whereas I call them 'trousers', Therefore thou art in hell-fire and may the Lord pity thee!" 
7 "Preferrest thou the gospel of Montreal to the gospel of Hellas, The gospel of thy connection with Mr. Spurgeon's haberdashery to the gospel of Discobolus?"

Yet none the less blasphemed he beauty saying, "The Discobolus hath no gospel, But my brother-in-law is haberdasher to Mr. Spurgeon."

O God! O Montreal!

* $\quad$ From The Blasted Pine: An Anthology of Satire, Invective and Disrespectful Verse, Chiefly by Canadian Writers, selected and arranged by F. R. Scott and A. J. M. Smith, Toronto, MacMillan, 1957 (1960), pp. 45-46.

\section{La nuit n $^{* *}$}

1 Caché dans une chambre de débarras de Montréal

Le Discobole en pénitence tourne son visage vers un mur;

Couverte de poussière et de toiles d'araignées, mutilée, vilipendée,

La Beauté crie dans un grenier, et nul ne se soucie d'elle.

\section{Ô Dieu! Ô Montréal!}

2 Beau en chaque heure du jour et de la nuit, beau en toute saison,

Entier ou mutilé, toujours beau malgré tout,

Il prêche l'évangile de la grâce à la peau des chouettes

Et à un homme qui prépare les peaux des chouettes canadiennes

Ô Dieu! Ô Montréal!

5 “Le Discobole a été mis là parce qu'il est vulgaire;

Il n'a ni veston ni inexprimables pour couvrir ses membres;

Moi, Monsieur, j'appartiens à une famille des plus comme-il-faut;

Mon beau-frère est le mercier de Monsieur Spurgeon".

\section{Ô Dieu! Ô Montréal!}

6 Alors je dis: "Ô beau-frère du mercier de Monsieur Spurgeon,

Qui prépares aussi les peaux des canadiennes chouettes,

Tu nommes "inexprimables" ce que j'appelle "culottes,"

Et pour cela tu brûles en enfer-que le Seigneur ait pitié de toi”!

Ô Dieu! Ô Montréal!

\section{Les confitures de coings ${ }^{* * *}$}

1 Caché dans une chambre de débarras de Montréal

Le discobole en pénitence tourne son visage vers un mur.

Couverte de poussière et de toiles d'araignées, mutilée, vilipendée,

La Beauté crie dans un grenier, et nul ne se soucie d'elle.

Ô Dieu! Ô Montréal!
5 ... Il expliqua que le Discobole n'était pas montré au musée de la ville à cause de sa nudité et que le gardien, rembourreur d'oiseaux, avait dit à Butler: "il est vulgaire; il n'a ni veston ni inexprimables pour couvrir ses membres. Moi, Monsieur, j'appartiens à une famille des plus comme il faut; mon beaufrère est le mercier de Monsieur Spurgeon". D'où la dernière strophe du poème.

6 Alors je dis: "O beau-frère du mercier de Monsieur Spurgeon,

Empailleur attitré de toutes les chouettes canadiennes,

Tu nommes "inexprimables" ce que j'appelle "culottes,"

Et pour cela tu brûles en enfer-que le Seigneur ait pitié de toi"!

Ô Dieu! Ô Montréal! 
- Le connaissiez-vous?

- Non, pas du tout.

- Nous n'existons donc pas pour vous! Pourtant, vous devriez le savoir: Montréal est une ville à direction écossaise.

[...]

- C'est moi, dit Frank, qui ai traduit ce poème.

$(1965,77-78)$

** Jacques Ferron, La nuit, Montréal, Parti Pris, 1965 , pp. $77-78$.
Frank me demanda si je connaissais ce poème. - Non, pas du tout.

Cela lui déplut.

- Nous n'existons donc pas pour vous!

Nous fîmes quelques pas en silence. Sans doute eut-il le temps de penser que la réciproque était vraie.

[...]

- Ô Dieu! Ô Montréal! fis-je, ce n'est pas dans les habitudes de vos compatriotes de se déprécier: ils peuvent tout mettre à notre compte en fait de ridicules et de sottises. Il doit exister une version de ce poème où le beau-frère du mercier de Monsieur Spurgeon est un brave CF, victime de ses curés.

- Possible, dit Frank.

Cela ne l'avait pas empêché de me le réciter.

$(1977,65-66)$

*** Jacques Ferron, Les confitures de coings, Montréal, Parti Pris, 1972 (1977), pp. 65. 